\title{
PENERAPAN TAKSONOMI BLOOM DALAM KEMAMPUAN BERPIKIR MENYELESAIKAN SOAL GEOMETRI PADA SISWA KELAS VIII
}

\author{
Yohana Regnisia Afirda ${ }^{1}$, Sofia Sa'o ${ }^{2}$, Yasinta Yenita Dhiki ${ }^{3}$ \\ ${ }^{1}$ Program Studi Pendidikan Matematika, Universitas Flores, Jln. Sam Ratulangi, Ende-Flores-NTT \\ ${ }^{2}$ Universitas Flores, Jln. Sam Ratulangi, Ende-Flores-NTT \\ ${ }^{3}$ Universitas Flores, Jln. Sam Ratulangi, Ende-Flores-NTT \\ Email: afirdayohana@gmail.com
}

\begin{abstract}
This research was conducted at SMP Negeri 2 Ende in the 2018/2019 school year. The purpose of this study was to describe: the ability to think in solving geometry problems in class VIII students using Bloom's taxonomy in the cognitive domain, the ability to think in solving geometric problems in class VIII students using Bloom's taxonomy in the affective domain, the ability to think in solving geometric problems in class VIII students using Bloom's taxonomy. psychomotor realm. This type of research is a descriptive study using qualitative methods. Data collection techniques using written tests, interviews, observation, and documentation. The subjects in this study were six students who were selected based on 3 groups of ability, namely high, medium, and low. The selection of research subjects was based on written test results. The results showed that based on Bloom's taxonomy, the thinking abilities of class VIII A students of SMP Negeri 2 Ende in solving geometry problems were as follows: in the higher thinking group the ability to think was at the level of analysis. Students in the medium ability group are at the application level and students in the low ability group are at the knowledge level.
\end{abstract}

Keywords: bloom's taxonomy; thinking ability; geometry

\begin{abstract}
Abstrak
Penelitian ini dilaksanakan di SMP Negeri 2 Ende pada tahun pelajaran 2018/2019. Tujuan penelitian ini adalah untuk mendeskripsikan: kemampuan berpikir menyelesaikan soal geometri pada siswa kelas VIII menggunakan taksonomi Bloom pada ranah kognitif, kemampuan berpikir menyelesaikan soal geometri pada siswa kelas VIII menggunakan taksonomi Bloom ranah afektif, kemampuan berpikir menyelesaikan soal geometri pada siswa kelas VIII menggunakan taksonomi Bloom ranah psikomotor. Jenis penelitian ini adalah penelitian deskriptif menggunakan metode kualitatif. Teknik pengumpulan data menggunakan tes tertulis, wawancara, observasi dan dokumentasi. Subjek dalam penelitian ini adalah Enam siswa yang dipilih berdasarkan 3 kelompok kemampuan yaitu tinggi, sedang dan rendah. Pemilihan subjek penelitian didasarkan pada hasil tes tertulis. Hasil penelitian menunjukkan bahwa berdasarkan taksonomi Bloom, kemampuan berpikir siswa kelas VIII A SMP Negeri 2 Ende dalam menyelesaikan soal geometri adalah sebagai berikut: dalam kelompok kemampuan berpikir tinggi berada pada tingkat analisis. Siswa kelompok kemampuan sedang berada pada tingkat aplikasi dan siswa kelompok kemampuan rendah berada pada tingkat pengetahuan.
\end{abstract}

Kata kunci:taksonomi bloom; kemampuan berpikir; geometri.

\section{PENDAHULUAN}

Kemampuan berpikir merupakan kegiatan penalaran yang reflektif, kritis, dan kreatif, berorientasi pada suatu proses intelektual dengan melibatkan pembentukan konsep, aplikasi, analisis, 
menilai informasi yang terkumpul atau dihasilkan melalui pengamatan, pengalaman, refleksi, atau komunikasi sebagai landasan pada suatu keyakinan dan tindakan. Kemampuan berpikir adalah salah satu faktor penting yang harus selalu diperhatikan oleh seorang guru karena apabila siswa dikatakan memiliki kemampuan berpikir yang baik jika hasil belajar siswa tersebut jauh lebih maksimal atau sesuai dengan kriteria ketuntasan minimal (KKM) di sekolah.

Guru sebagai sumber sekaligus penggerak dalam mengelola kelas pada proses pembelajaran agar berjalan dengan baik dan akhirnya mencapai tujuan yang telah direncanakan. Namun dalam keseluruhan proses pendidikan di sekolah, pembelajaran di kelas sering mengalami kesulitan, karena masih banyak siswa yang kurang kreatif dalam mengembangkan kemampuan berpikirnya. Menurut King (2016) secara formal, berpikir melibatkan proses penggunaan informasi secara mental dengan cara membentuk konsep, memecahkan masalah, mengambil keputusan, dan memperlihatkannya dalam cara yang kritis atau kreatif. Namun kenyataanya, kemampuan berpikir siswa terbatasi oleh contoh-contoh soal yang diberikan oleh guru. Siswa lebih cenderung senang belajar dengan tipe soal yang hampir sama dengan contoh dan jarang menggunakan tipe soal yang berbeda. Ketika siswa dihadapkan pada soal yang lebih sulit dan sedikit berbeda dengan contoh, siswa mengalami kesulitan dalam menyelesaikan soal. Saat siswa merasa tidak mampu menyelesaikan soal, mereka cenderung mengandalkan apa yang dicontohkan guru. Akibatnya, kurang berkembangnya kemampuan kreativitas siswa.

Permasalahan yang terjadi saat dilakukan pra penelitian antara lain Kesulitan guru membuat soal-soal matematika yang dapat meningkatkan kemampuan berpikir siswa. Guru lebih dominan membuat soal-soal rutin atau pertanyaan tingkat rendah, dan juga Soal yang diberikan tidak berhubungan dengan kehidupan sehari-hari sehingga siswa mengalami kesulitan dalam mengaplikasikan konsep matematika dalam kehidupan sehari-hari.

Untuk mendukung pembelajaran matematika khususnya dalam meningkatkan kemampuan berpikir siswa, dalam pendidikan terdapat teori Taksonomi Bloom. Teori Taksonomi Bloom ini mengarahkan guru untuk mengolah siswa dalam tiga aspek, yaitu: aspek kognitif, afektif dan psikomotor. Aspek kognitif merupakan kemampuan yang berkaitan dengan penguasaan ilmu pengetahuan dan teknologi (Subini, 2012). Aspek afektif merupakan suatu domain yang berkaitan dengan sikap, nilai, apresiasi (penghargaan) dan penyesuaian perasaan sosial (Uno \& Nurdin 2015).

Berikutnya aspek psikomotor merupakan ranah yang berkaitan dengan aspek-aspek keterampilan yang melibatkan fungsi sistem saraf dan otot dan fungsi psikis. Ranah ini terdiri dari kesiapan, peniruan, membiasakan, menyesuaikan, dan menciptakan (Haryati, 2009). Keterampilan melakukan sesuatu tersebut meliputi keterampilan motorik, keterampilan intelektual dan keterampilan sosial. Agar mengetahui sejauh mana tujuan yang telah ditetapkan itu tercapai atau berhasil, maka diperlukan adanya evaluasi. Salah satu prinsip dasar yang harus diperhatikan dalam rangka 
mengadakan evaluasi adalah pemahaman terhadap materi atau bahan pelajaran yang telah diberikan (aspek kognitif), maupun segi penghayatan (aspek afektif), dan pengalaman (aspek psikomotor).

Menurut Nasution (2008) berpikir sebagai proses relektif yang pada dasarnya tak berbeda dengan berpikir ilmiah. Maksud dari berpikir relektif yaitu menggabungkan antara proses induktif dan proses deduktif. Berpikir induktif yaitu pengumpulan data, sedangkan proses deduktif yaitu mencari, menganalisis, dan menguji hipotesis. Perbedaan antara berpikir ilmiah dan berpikir relektif yaitu berpikir relektif dapat digunakan untuk memecahkan berbagai macam masalah termasuk masalah sosial. Adapun langkah-langkah pemecahan masalah menurut Dewey (Nasution 2008) yaitu mengenal dan merumuskan masalah, merumuskan hipotesis yaitu memungkinkan jawaban dalam bentuk generalisasi yang ditemukan sendiri yang harus diuji kebenarannya, menyelidiki implikasi hipotesis dengan mengumpulkan data atau pengetahuan, mengetes hipotesis dengan menguji implikasi atau konsekuensi hipotesis berdasarkan data atau pengalaman, mengambil kesimpulan yaitu menerima hipotesis, menolaknya, memodifikasinya, atau menyatakan bahwa berdasarkan data yang ada belum dapat diambil kesimpulan. Apabila seorang siswa telah berpikir dalam memecahkan suatu permasalahan yang dihadapi, maka pada diri siswa tersebut terjadi suatu proses berpikir yang menurut Suryabrata (2001) melalui tiga tahap yaitu pembentukan pengertian, pembentukan pendapat dan penarikan kesimpulan. Selanjutnya tugas dari seorang guru yaitu dituntut untuk mampu mengembangkan kemampuan berpikir untuk setiap siswanya, dengan harapan siswanya akan mampu memecahkan masalah dan dapat memberikan pendapat sehingga terbentuklah suatu kesimpulan. Siswa yang mampu memecahkan suatu permasalahan serta dapat menyelesaikannya dengan baik maka dapat dikatakan kemampuan berpikir dan kerja pikir siswa tersebut baik.

Sutanto (2013) mengatakan bahwa pembelajaran matematika merupakan suatu proses belajar mengajar yang dibangun oleh guru untuk mengembangkan kemampuan berpikir siswa serta dapat meningkatkan kemampuan mengkontruksi pengetahuan baru sebagai upaya peningkatan penguasaan yang baik terhadap materi matematika. Sedangkan menurut Muhsetyo (2008), pembelajaran matematika adalah proses pemberian pengalaman belajar kepada siswa melalui serangkaian kegiata yang terencana sehingga siswa memperoleh kompetensi tentang bahan matematika yang dipelajari. Berdasarkan penjelasan di atas dapat disimpulkan bahwa pembelajaran matematika merupakan kegiatan belajar dan mengajar ilmu dengan tujuan membangun pengetahuan matematika agar bermanfaat dan mampu memperaktekkan hasil belajar matematika dalam kehidupan sehari-hari.

Menurut Sodjadi (2000), secara umum tujuan diberikannya matematika di sekolah adalah untuk membantu siswa mempersiapkan diri agar sanggup menghadapi perubahan keadaan di dalam kehidupan dan di dunia yang selalu berkembang melalui latihan bertindak atas dasar pemikiran yang logis, rasional dan kritis serta mempersiapkan siswa agar dapat menggunakan matematika dan pola pikir matematika dalam kehidupan sehari-hari dan dalam mempelajari ilmu pengetahuan lain. 
Secara khusus tujuan pembelajaran matematika menurut Depdiknas (Susanto, 2013) antara lain 1) memahami konsep matematika, menjelaskan keterkaitan antar konsep dan mengaplikasikan konsep atau algoritma, 2) menggunakan penalaran pada pola dan sifat, melakukan manipulasi matematika dalam generalisasi, menyusun bukti atau menjelaskan gagasan dan pernyataan matematika, 3) memecahkan masalah yang meliputi kemampuan memahami masalah, merancang model matematika, menyelesaikan model dan menafsirkan solusi yang diperoleh, 4) mengkomunikasikan gagasan dengan simbol, tabel, diagram, atau media lain untuk menjelaskan keadaan atau masalah, 5) memiliki sikap menghargai penggunaan matematika dalam kehidupan sehari-hari.

\section{METODE}

Jenis penelitian ini yaitu penelitian deskriptif dengan pendekatan kualitatif. Menurut Moelong (2011), penelitian kualitatif adalah penelitian yang bermaksud untuk memahami fenomena tentang apa yang dialami oleh subyek penelitian misalnya perilaku, persepsi, motivasi, tindakan secara holistik dengan cara deskripsi dalam bentuk kata-kata dan bahasa, pada suatu konteks khusus yang alamiah dan dengan memanfaatkan berbagai metode ilmiah.

Penelitian ini bertujuan untuk mengetahui data responden secara langsung dari lapangan, yakni mengetahui situasi atau keadaan sebenarnya tentang penerapan taksonomi Bloom dalam meningkatkan kemampuan berpikir matematika siswa. Penelitian ini dilaksanakan di kelas VIII di SMP Negeri 2 Ende tahun pelajaran 2018/2019. Subjek dalam penelitian ini adalah guru mata pelajaran matematika dan siswa kelas VIIIA. Jumlah siswa dalam penelitian ini sebanyak 33 orang. Teknik pengumpulan data menggunakan tes tertulis, wawancara, observasi dan dokumentasi. Teknik analisis data yang digunakan yaitu 1) reduksi data yaitu proses pemilihan, pemusatan perhatian pada penyederhanaan data, pengabstrakan dari transformasi data besar yang muncul dari catatan-catatan tertulis di lapangan. Reduksi data berlangsung secara kontinuitas selama kegiatan yang berorientasi kualitatif berlangsung. Selama pengumpulan data terjadi reduksi berikutnya yakni sebagai kegiatan membuat ringkasan, mengkode, menelusuri tema, membuat gugus-gugus dan membuat partisi memo. 2) penyajian data yaitu penyajian sekumpulan informasi sistematis yang memberikan kemungkinan adanya penarikan kesimpulan dan pengambilan tindakan. Penyajian tersebut dapat berbentuk matriks, grafik, jaringan dan bagan, 3) penarikan kesimpulan atau verifikasi dilakukan sejak permulaan, pengumpulan data, pembuatan pola-pola, penjelasan konfigurasi-konfigurasi yang mungkin dan alur sebab akibat serta proposisi.

Keabsahan data merupakan suatu yang sangat penting dalam penelitian karena akan menjamin kepercayaan data tersebut. Untuk melakukan pengecekan keabsahan data teknik yang digunakan dalam penelitian ini adalah triangulasi. Triangulasi melakukan pengecekan data dari berbagai sumber dengan berbagai cara dan berbagai waktu. Dalam hal ini untuk mengecek keabsahan data, peneliti 
menggunakan triangulasi teknik menurut Anis Fuad (2014). Proses triangulasi yang digunakan peneliti meliputi 3 sumber data yaitu data hasil observasi, data hasil wawancara dan data hasil dokumentasi. Data dari ketiga teknik tersebut dapat dibandingkan adalah konsistensi, jika berbeda dijadikan catatan dan dilakukan pengecekkan selanjutnya, mengapa data bisa berbeda.

\section{HASIL DAN PEMBAHASAN}

Dalam proses pembelajaran, guru menyampaikan materi segitiga. Guru menjelaskan materi secara detail dan memberikan contoh yang terkait dengan kehidupan sehari-hari sehingga siswa paham tentang materi yang disampaikan. Hal ini untuk menekankan pada aspek kognitif siswa. Guru juga mempersilahkan atau memberikan peluang kepada siswa maju ke depan kelas untuk menjawab soal latihan agar aspek psikomotor siswa dapat terlatih secara maksimal. Guru menjawab pertanyaanpertanyaan dari siswa yang belum menguasai materi. Selain itu, guru juga menggunakan bahasa yang sederhana untuk mempermudah komunikasi terhadap siswa dan melatih sikap percaya diri untuk berani mengungkapkan jawaban yang sesuai. Guru juga bersikap adil terhadap siswa. Guru memulai pelajaran dengan ceria agar siswa ikut merasakan hal yang sama. Hal ini menunjukkan guru memperhatikan aspek afektif terhadap siswa. Guru juga sering memberikan intermezzo agar pembelajaran tidak monoton sehingga siswa tidak merasa jenuh atau bosan. Guru juga mengalokasikan waktu pembelajaran sesuai dengan tahap-tahap pembelajaran. Selain itu guru juga memberikan reward kepada siswa yang bisa menjawab soal agar siswa semangat dalam belajar. Sistem pembelajaran ini menekankan aspek kognitif, aspek afektif dan psikomotor sebagai implementasi taksonomi Bloom.

Berdasarkan jadwal yang telah disepakati pada hari jumat tanggal 24 mei 2019 peneliti melakukan observasi di kelas VIII A SMP Negeri 2 Ende peneliti mengamati dan mencatat keadaan siswa pada saat pembelajaran berlangsung. Siswa didampingi oleh guru mata pelajaran matematika. Hasil pengamatan adalah pembelajaran dimulai pukul 09.45 sedangkan jadwal mulai pembelajaran adalah 09.15. Pembelajaran berlangsung tiga jam pelajaran ( 3 x 40 menit). Guru menyampaikan materi seputar bangun datar segitiga (luas dan keliling segitiga )dengan menggunakan metode ceramah. Sementara sebagian siswa mencatat materi yang disampaikan peneliti. Bahan ajar yang dipakai di kelas tersebut sebatas buku paket matematika milik perpustakaan sekolah dan catatan yang diberikan setiap pembelajaran berlangsung. Sebagian siswa mengikuti pembelajaran secara aktif dengan mengajukan berbagai pertanyaan kepada peneliti. Namun, keaktifan tersebut hanya didominasi oleh siswa perempuan. Terdapat beberapa siswa yang tidak termotivasi mengikuti pembelajaran matematika. Mereka menunjukkan sifat kepasifannya seperti meletakkan kepala di atas meja, mengantuk, tidak memperhatikan penjelasan guru dan membuat pekerjaan mereka sendiri.

Setelah selesai menjelaskan materi, selanjutnya adalah pemberian latihan soal mengenai luas dan keliling segitiga. Soal berbentuk uraian dengan tingkatan soal adalah pengetahuan, pemahaman, 
penerapan, dan evluasi. Siswa mengerjakan soal dengan tertib. Terdapat beberapa siswa yang begitu aktif dan beberapa yang cenderung pasif. Hasil jawaban siswa berupa jawaban uraian dengan tingkatan penerapan materi segitiga sebagaimana yang biasa mereka kerjakan. Selanjutnya hasil jawaban didiskusikan dengan peneliti dan semua siswa. Salah satu siswa menuliskan jawaban di papan tulis sekaligus menjelaskan maksud dari jawaban mereka. Hal itu dilakukan siswa sampai seluruh jawaban soal terselesaikan. Peneliti bertugas menjadi penengah dan meluruskan jawaban siswa yang belum lengkap. Peneliti menutup pembelajaran pada pukul 11.30 dengan memberikan motivasi dan pekerjaan rumah.

Tes dilaksanakan pada hari sabtu 25 mei 2019 pada pukul 07.00-09.30. Siswa diberikan soal tes yang sama untuk dikerjakan. Soal tes terdiri dari 5 butir soal uraian. Hasil tes tertulis diperiksa menggunakan pedoman penskoran yaitu untuk soal nomor 1 jika benar diberi skor 4 . Untuk soal nomor 2 dan 3 diberi skor benar minimal 3,5 dan maksimalnya 5 tergantung langkah penyelesaiannya. Berdasarkan hasil tes tertulis, dapat diketahui bahwa terdapat tiga kelompok kemampuan berpikir dalam menyelesaikan soal berdasarkan taksonomi Bloom yakni siswa dengan kemampuan tinggi, sedang dan rendah. Kelompok siswa berkemampuan tinggi adalah siswa yang mencapai nilai lebih dari KKM (Kriteria Ketuntasan Minimal) yang berkisar antara 85-100. Kelompok siswa berkemampuan sedang adalah siswa yang memperoleh nilai antara 70-85. Sedangkan kelompok siswa berkemampuan rendah adalah yang memperoleh nilai di bawah KKM atau nilai yang berkisar antara 0-69. Ketiga kelompok kemampuan tersebut akan peneliti gunakan sebagai subjek wawancara.

Berdasarkan hasil tes tertulis, terdapat 3 kelompok kemampuan berpikir, yakni tinggi, sedang dan rendah. Dari ketiga kelompok kemampuan tersebut peneliti memilih 2 siswa untuk dijadikan subyek wawancara. Peneliti melaksanakan wawancara tanpa didampingi oleh guru mata pelajaran matematika. Alasan peneliti melaksanakan wawancara didalam jam pelajaran karena guru mata pelajaran telah mengijinkan peneliti melakukan wawancara pada jam tersebut. Selain itu guru mata pelajaran telah memberi kesempatan sepenuhnya kepada peneliti jika kelas tersebut akan dipakai untuk penelitian kapan saja. Guru kelas memanfaatkan waktu ini untuk mendapatkan wawasan baru yang nantinya akan bermanfaat bagi siswa itu sendiri. Selanjutnya peneliti melakukan wawancara dengan guru mata pelajaran matematika. Wawancara ini dilakukan di kantor guru. Dengan tujuan untuk mengklarifikasi hasil tes tertulis dan wawancara dengan siswa. Dari wawancara tersebut nantinya menghasilkan data yang akan mendukung hasil tes dan wawancara dengan siswa serta mengetahui secara pasti penyebab dari permasalahan yang muncul pada siswa. Berdasarkan jawaban soal tes tertulis dan wawancara, dapat disimpulkan bahwa dari ketiga kemampuan tersebut siswa telah memunculkan tingkat kemampuan berpikir berdasarkan taksonomi bloom.

Berdasarkan hasil tes dan wawancara dengan ketiga kelompok kemampuan berpikir tingkat tinggi, sedang dan rendah dapat diketahui bahwa siswa kelas VIIIA SMP Negeri 2 Ende memiliki 
kemampuan yang baik dalam menyelesaikan soal geometri (segitiga). Hal tersebut juga akan didukung dengan hasil wawancara guru mata pelajaran matematika. Berdasarkan pengakuan dari guru mata pelajaran matematika kelas VIIIA SMP Negeri 2 Ende, siswa memang cenderung lebih mampu mengerjakan soal pada tingkat aplikasi. Hal itu disebabkan siswa hanya memahami apa yang disampaikan guru dan mengacu pada contoh soal sebelumnya yag sudah dibahas bersama guru. Siswa kurang mampu menyelesaikan soal pada tingkat yang lainnya. Sebagaimana cuplikan wawancara di atas, ketika peneliti memberikan soal pembuktian dengan tingkat analisis dan evaluasi, siswa justru mengerjakannya dengan pembuktian tingkat aplikasi.

Guru kelas juga mengakui bahwa ia hanya menyampaikan materi sampai pada tingkat aplikasi saja dalam taksonomi bloom. Alasannya adalah guru menganggap bahwa siswa lebih mudah memahami contoh soal daripada konsep suatu rumus segitiga. Jika siswa memahami rumus dan sulit mengaplikasikannya dalam soal maka itu dirasa percuma saja. Kasus yang lain adalah siswa kurang tertarik untuk memahami dan menganalisa soal. Sehingga sebelum mencoba mengerjakan soal, siswa sudah menganggap soal tersebut sulit. Selain itu, setiap model soal yang baru dianggap sebagai soal yang kompleks. Hal ini diakui oleh guru kelas. Siswa selalu berharap mendapatkan soal yang sama dengan sudah dipelajari sebelumnya. Siswa kurang mampu memahami soal yang menggunakan model berbeda dari biasanya. Sedangkan soal yang didasarkan pada taksonomi bloom sebagaimana peneliti sajikan termasuk soal kategori baru bagi siswa kelas VIIIA SMP Negeri 2 Ende. Jadi, kemampuan berpikir siswa lebih keingatan terhadap pembelajaran sebelumnya daripada proses berpikir yang membutuhkan analisa dan pemahaman.

Berdasarkan hasil observasi, tes tertulis dan wawancara, peneliti mengetahui hasil atau jawaban dari rumusan masalah yang telah disusun yaitu tentang bagaimana kemampuan berpikir menyelesaikan soal geometri (segitiga) siswa kelas VIIIA SMP Negeri 2 Ende menggunakan teori taksonomi Bloom (ranah kognitif, afektif dan psikomotor).

Penerapan taksonomi bloom ranah kognitif dapat dilihat pada hasil observasi, tes dan wawancara Tes dilaksanakan di kelas VIIIA SMP Negeri 2 Ende. Tes berupa soal uraian yang terdiri dari soal. Siswa diberikan waktu 90 menit untuk mengerjakan soal terkait dengan materi segitiga yang telah diberikan. Waktu yang diberikan diharapkan dapat digunakan sebaik-baiknya oleh siswa untuk menyelesaikan soal dengan teliti, baik dan benar. Setelah tes selesai, peneliti mengoreksi hasil pekerjaan siswa. Hasil pekerjaan siswa berguna untuk mengetahui tingkatan berpikir kognitif siswa berdasarkan taksonomi Bloom. Pada penelitian ini, subyek penelitian tidak dipilih secara acak, melainkan dengan sampel bertujuan. Sampel bertujuan memfokuskan pada informan-informan yang telah terpilih untuk dilakukan wawancara. Pemilihan subyek dalam penelitian ini diambil dari 33 siswa kelas VIII A SMP Negeri 2 Ende yang mengikuti tes tertulis dan telah diklasifikasikan berdasarkan interpretasi proses kognitif dalam taksonomi Bloom. Melalui pengelompokkan tersebut, 
terpilih 6 siswa yang dijadikan sebagai subyek penelitian yaitu 2 siswa dari kategori tingkatan berpikir tinggi, 2 siswa kategori berpikir rendah dan 2 siswa yang berada pada kategori berpikir rendah.

Mengingat adalah kemampuan memperoleh kembali pengetahuan dari memori jangka panjang. Dari hasil tes dan wawancara diperoleh bahwa dari ketiga kelompok kemampuan siswa berhasil mengerjakan soal dengan benar. Hal ini menunjukkan bahwa ketiga kelompok tersebut memiliki kemampuan mengingat yang baik.

Memahami adalah kemampuan membangun makna dari pesan pembelajaran dan mampu mengkomunikasikan dalam bentuk lisan, tulisan maupun grafik. Siswa memahami ketika mereka mampu menentukan hubungan antara pengetahuan yang baru diperoleh dengan pengetahuan mereka sebelumnya. Dari hasil tes diperoleh indikator pemahaman hanya dicapai oleh siswa dengan kategori kemampuan tingkat tinggi dan sedang. Sedangkan kategori tingkat rendah tidak dapat mencapai indikator yang telah ditetapkan.

Menerapkan adalah kemampuan menggunakan prosedur untuk menyelesaikan masalah. Indikator penerapan dapat dicapai oleh siswa dengan kelompok kemampuan tinggi dan sedang, sedangkan siswa dengan kemampuan rendah belum bisa. Hal ini sesuai dengan penelitian yang dilakukan oleh Zuchdi (2007) bahwa hasil belajar seorang siswa bisa saja mengalami peningkatan sesuai proses pembelajaran matematika atau sesuai proses pemberian tes matematika di kelas.

Menganalisis meliputi kemampuan untuk memecahkan suatu kesatuan menjadi bagian-bagian dan menentukan bagaimana bagian-bagian tersebut dihubungkan satu dengan yang lainnya atau bagian tersebut dengan keseluruhan. Analisis menekankan pada kemampuan merinci unsur pokok menjadi bagian-bagian dan melihat hubungan antara bagian-bagian tersebut. Indikator analisis hanya dapat dicapai oleh siswa yang memiliki kemampuan tinggi. Sedangkan siswa kelompok sedang dan rendah belum dapat mencapai indikator tersebut. Siswa berkemampuan tinggi mampu mentransformasikan informasi yang tersaji pada soal kedalam sebuah gambar ilustrasi. Lain halnya dengan siswa kelompok sedang dan rendah setelah mentransformasikan informasi pada soal kedalam sebuah gambar siswa tidak dapat menyelesaikan soal yang disajikan.

Ranah afektif berkenaan dengan sikap dan nilai. Ranah afektif tidak dapat diukur seperti halnya ranah kognitif. Skala yang digunakan untuk mengukur ranah afektif siswa diantaranya skala sikap. Berdasarkan hasil observasi di SMP Negeri 2 Ende, ranah afektif tampak pada siswa dalam berbagai hal seperti perhatiannya terhadap pelajaran. Ketepatan dalam menjawab soal-soal yang diberikan guru seperti langkah-langkah dan prosedur pengerjaan yang sesuai. Kedisiplinan dalam mengikuti pelajaran matematika. Memiliki motivasi yang tinggi untuk tahu lebih banyak mengenai materi segitiga serta menghargai guru dan teman sekelas.

Ranah psikomotor tampak dalam bentuk keterampilan dan kemampuan bertindak individu. Hasil belajar psikomotor ini sebenarnya merupakan kelanjutan dari aspek kognitif dan afektif. Hasil 
belajar kognitif dan afektif akan menjadi hasil psikomotor apabila siswa telah menunjukkan perilaku atau perbuatan tertentu. Penilaian ranah psikomotor dilakukan menggunakan observasi. Observasi dilakukan saat proses kegiatan belajar mengajar. Hasil observasi ranah psikomotor pada pembelajaran matematika adalah sebagai berikut: siswa mengerjakan soal sampai tuntas. siswa bertanya kepada guru tentang contoh-contoh yang berkaitan dengan materi segitiga. Siswa mencari dan membaca buku-buku yang berkaitan dengan materi segitiga. Siswa dapat memberikan penjelasan kepada temanteman sekelasnya tentang materi segitiga. Siswa mampu menggambar jenis- jenis segitiga.

Ketiga aspek memiliki hubungan yang sangat erat dan tidak dapat dipisahkan. Sebelum sampai kepada aspek psikomotorik, terlebih dahulu siswa akan mengalami tahap kognitif dan afektif. Pada tahap penerimaan, siswa terlebih dahulu perlu memiliki suatu perhatian untuk dapat menerima materi yang diberikan. Dengan adanya perhatian, maka akan mudah bagi siswa menerima pengetahuan tersebut dan seterusnya. Dalam setiap aspek afektif, terbukti memiliki aspek kognitif di dalamnya untuk saling mendukung. Setelah siswa melalui tahap kognitif dan afektif, maka ia akan siap untuk melanjutkan kepada tahap psikomotorik berdasarkan apa yang sudah dipelajarinya dikedua tahap sebelumnya. Aspek-aspek ini sebagai dasar untuk memberikan pengajaran atau pembelajaran kepada siswa, hasil tidak saja akan membuat siswa mengerti tentang konsep pelajaran secara menyeluruh, namun juga akan mengembangkan kemampuan emosional serta motorik siswa pada saat yang bersamaan.

Aspek-aspek ini membantu para guru untuk mengenali pada tahap mana kemampuan masingmasing siswa. Hal itu akan membantu para guru untuk menciptakan instruksi yang mengarah kepada kemampuan berpikir kritis untuk masing-masing siswa. Pembelajaran tanpa mengenal konsep dasar atau kemampuan berpikir kritis akan sulit untuk diterapkan dan pada akhirnya hanya akan membiasakan siswa untuk mengenali teori tanpa mengerti dasar-dasar dari pengetahuan yang dimilikinya, dan pada akhirnya akan membuatnya sulit untuk menerapkan pengetahuannya tersebut dalam berbagai situasi. Contohnya, memiliki kemampuan berhitung akan sia-sia tanpa kemampuan untuk mengetahui bagaimana, kapan, dan apa cara mengaplikasikan hitungan tersebut dalam dunia nyata. Penerapan aspek kognitif, afektif, dan psikomotorik akan membantu anak mengembangkan kemampuan dirinya secara menyeluruh, dan tidak sebagian saja.

\section{KESIMPULAN}

Berdasarkan hasil penelitian dan pembahasan, dapat disimpulkan bahwa 1) Kemampuan berpikir ranah kognitif dalam menyelesaikan soal geometri pada siswa kelas VIII A SMP Negeri 2 Ende memenuhi kriteria pemahaman dan penerapan, sedangkan siswa mengalami kesulitan pada kriteria aplikasi dan evaluasi. 2) Kemampuan berpikir ranah afektif dalam menyelesaikan soal geometri pada siswa kelas VIII A SMP Negeri 2 Ende mengalami kesulitan menentukan langkah- 
Penerapan Taksonomi Bloom Dalam Kemampuan Berpikir Menyelesaikan Soal Geometri Pada Siswa Kelas VIII Yohana Regnisia Afirda ${ }^{1}$, Sofia $\mathrm{Sa}^{\prime}{ }^{2}$, Yasinta Yenita Dhiki ${ }^{3}$

Jupika: Jurnal Pendidikan Matematika, Volume 3. Nomor 2. September 2020. Hal.121-130

langkah yang tepat dalam menyelesaikan soal, seperti urutan penyelesaian soal. 3) Kemampuan berpikir ranah psikomotor dalam menyelesaikan soal geometri pada siswa kelas VIII A SMP Negeri 2 Ende memenuhi kriteria dalam aspek psikomotor. Hal ini dapat dilihat dari kemampuan siswa dalam menyelesaikan soal. Misalnya siswa menjawab soal sampai selesai.

\section{DAFTAR PUSTAKA}

Anis Fuad, K. S. N. (2014). Panduan Praktis Penelitian Kualitatif. Graha Ilmu.

Haryati, M. (2009). Model Dan Teknik Penilaian Pada Tingkat Satuan Pendidikan. Jakarta: Gaung Persada Press.

King, L. A. (2016). Psikologi Umum: Sebuah Pandangan Apresiatif. Jakarta: Salemba Humanika. Moleong, L.J. (2011). Metodologi Penelitian Kualitatif Edisi Revisi. Bandung: PT. Remaja Rosdakarya.

Muhsetyo, G. (2008). Pembelajaran Matematika SD. Jakarta: UT.

Nasution. (2008). Berbagai Pendekatan dalam Proses Belajar \& Mengajar. Cetakan keduabelas. Jakarta : Bumi Aksara.

Soedjadi. (2000). Kiat Pendidikan Matematika di Indonesia:Konstanta Keadaan Masa Kini Menuju Harapan Masa Depan. Jakarta: Dirjen Dikti, Departemen Pendidikan Nasional.

Subini, Nini. (2012). Psikologi Pembelajaran. Yogyakarta: Mentari Pustaka.

Suryabrata, S. (2001). Psikologi Kepribadian. Cetakan ke 4. Jakarta: Raja Grafindo Pustaka.

Susanto, A. (2013). Teori Belajar dan Pembelajaran di Sekolah Dasar. Jakarta: Kencana Prenada Media Group

Uno, Hamzah., Nurdin, M. (2015). Belajar dengan Pendekatan P-A-IL-K-E-M. Jakarta: PT. Bumi Aksara.

Zuchdi, Darmiyati. (2011). Pendidikan Karakter dalam Prespektif Teori dan Praktek. Yogyakarta: UNY Press. 